\title{
Learning to live with the law? The legislative attack on British trade unions since 1979
}

\author{
Linda Dickens*
}

This article takes as its focus the labour legislation of the Conservative governments in Britain under Mrs. Thatcher since 1979. It locates the legislation in its broader context and examines three main prongs of what is seen as a legislative attack on the trade unions: the move away from collective industrial relations; the restricted terrain for lawful industrial action; and legal intervention in internal union affairs. The immediate impact, use of and response to this legislation is discussed and a broader question raised concerning whether, as well as having to adjust to the new legal framework, British trade unions are reappraising their attitude to the role of law in industrial relations more generally.

\section{Introduction - how the position has changed}

Twenty or so years ago, appearing before a Royal Commission investigating the possible extension of legal regulation in the field of industrial relations, the then General Secretary of the National Union of Railwaymen expressed a view that encapsulated the dominant trade union view about such regulation. Addressing the Chairman, Lord Donovan, he said;

I would be much happier, with great respect to you, my Lord, if we didn't have anything to do with the law at all (Flanders, 1974, p. 352).

This was, of course, an endorsement of voluntarism, an endorsement of the system of legal abstention seen as characteristic of the British system of industrial relations. The voluntarist, legal abstention approach placed collective bargaining centre stage. The parties - unions and employers - voluntarily determined the terms and conditions of employment. Although there was some legal enactment, it was of a kind designed to support or supplement the autonomous, self-regulated system. There was little legal regulation of the internal affairs of the parties to collective bargaining; their agreements were not regarded as legal contracts, they were free to use their collective strength and, importantly, the courts were kept out of industrial relations. In the words of Kahn Freund's oft quoted observation:

* School of Industrial and Business Studies, University of Warwick. An earlier version of this paper was presented in July 1988 to a Colloquium organised by the Industrial Relations Research Institute, University of Wisconsin-Madison, where the author was Visiting Professor. 
There is perhaps no country in the world in which the law has played a less significant role in the shaping of industrial relations than in Great Britain and in which today the law and the legal profession have less to do with labour relations (Kahn-Freund, 1954, p. 44)

That observation was made in 1954. Postwar students of industrial relations when that academic subject was in its infancy in Britain, therefore, were required to spend little time on the study of labour legislation. In the 1980s things are much changed. The volume of labour legislation has increased considerably - six major statutes have been passed since 1980 alone - and, in contrast to the legal regulation which was accommodated within the voluntarist system, this is law of a restrictive, interventionist kind, designed to within the voluntarist system, collective bargaining rather than support it.

To describe the labour legislation since 1979 - when the Conservative Party under Mrs
downlay collective bargaining rather than support it. Thatcher came to office - as a 'legislative attack' on the trade unions is clearly a value judgment as well as a description of how the trade union movement perceives it. It is, nonetheless, a description which receives some support from those responsible for it. The Secretary for State responsible for the passage of the Employment Act 1982, for example, talked of seeking to 'neuter' the trade unions. More usually, however, the legislative talked of seeking to neuter the trade unions. More usually, however, the legislative
intention is portrayed less graphically as seeking to redress both the balance between employers and the unions (a balance which it is argued swung too much in the unions' favour during the period of Labour administration in the mid-1970s), and the balance between individual liberty and freedom and collective organisation (for example, $\mathrm{Mr}$. Tebbit, Secretary of State for Employment, Parl. Deb. H.C. Feb 8 1982).

Because of the change of government in 1979, bringing quite clear shifts in public policy concerning industrial relations after the period of the Labour Government's 'Social Contract' with the unions, that year provides a convenient starting point for us. But I do not wish to imply that the voluntarist system was thriving until then, nor that all the problems facing British trade unions came into being at that time. Voluntarism had been under question since the mid-1960s, and many of the problems facing British trade unions in the 1980s, which form part of the context within which the 'legislative attack' has been experienced, developed over a longer term. As will be discussed below, the impact and perception of legislation itself depends in part on the context within which it is enacted since 'a healthy trade union movement can "take" a great deal of legal intervention, whilst weak trade unions may be its victim' (Kahn-Freund, 1977, p. 121). The problems facing the trade unions, however, have been overlain and exacerbated by the policies adopted by the three Thatcher administrations. These policies extend beyond the legislative to include the abandonment of the post-war consensus on maintaining a 'full employment' economy. Unemployment in this decade has reached its highest levels since the depression of the 1930s.

Given the attack on trade union power, we need to consider briefly why trade union power was seen as a matter of concern by the incoming Conservative administration in 1979. Various threads underlying the attack may be drawn together. Firstly, there is the tradition of individualism in the Conservative ideology which sees trade union power as a threat to individual freedom. Secondly, there was the rancour at the defeat of the previous Conservative Government, under Prime Minister Heath in 1974, popularly presented as a defeat at the hands of powerful trade unions. Then there is the perceived failure of the Labour Government in the intervening years to deal with trade union power through a 'corporatist' approach; drawing the unions into the economic management of the country and enacting agreed legislation and social policy in return for wage restraint. This socalled 'Social Contract' ended in a period of widespread industrial action, particularly among public sector workers, and the defeat of the Labour Government. This provided both a suitable backcloth, and public support, for the Conservative's intention to tackle union power. But more important than these threads is the link between the economic policy' and legislative policy of the government. Strong trade unions with monopoly power are seen as a barrier to the government's desired economic and fiscal policy: trade union power interferes with the free operation of the labour market and therefore must be reduced (see, for example, MacInnes, 1987, ch. 4; Wedderburn, 1986, pp. 83-6; and reduced (see, for example,
Hayek, 1980, pp. 51-8).

The interlinking of legislative and economic policy also goes hand in hand with the government's policy towards its role as employer in the state sector where trade unions were seen to wield damaging monopoly power. Britain has witnessed a marked change in the role of the state as employer in the public sector (or what is left of it). The size of the public sector has been reduced by selling off sections of it to the private sector. Telecommunications, shipbuilding, the gas industry, British Aerospace, the National Bus Company and British Petroleum have already been 'privatised' in this way, alongside some 30 or more others, and the electricity and water industries are on the action list. Also, services such as cleaning and catering previously performed in public sector organisations by in-house workers have been 'contracted out' to private sector firms. Such contracting out is now compulsory for local authorities (for example in schools) and for the health service. This is seen as opening up the public sector to competition, also achieved through weakening public sector monopolies in the product market and through changed through weakening public sector monopolies in the product market and through changed
financing arrangements, designed to influence management policy, including its policy towards trade unions.

The nature of the 'good employer' model which the British public sector has long provided has changed. Public sector management is being encouraged to end what are seen as its cosy, collusive arrangements with trade unions (until 1979 valued as stable consultative industrial relations arrangements) in order to regain the 'right to manage'. This does not normally extend to withdrawing recognition rights, although in a few instances this has occured. Rather it is a more 'hard-nosed', at times confrontational, management style which is adopted (Beaumont, 1987; Ferner and Terry, 1985; and Ferner, 1985). Where the old legislation in support of collective bargaining and trade unionism gets in the way of this new approach it is repealed. Thus we have seen the recission of the long-established Fair Wages Resolution which prevented the undertaking of public contracts on inferior terms. (In fact, the process has been thrown into reverse with the Local Government Act 1988 explicitly preventing employment conditions being taken into account in the awarding of public contracts.) To remove the FWR the British Government had to renounce ILO Convention 94, which, ironically, had its origin in the earlier enlightened British practice. The move away from international standards is reflected also in the condemnation of the British Government under ILO Convention 98 following the abolition of collective bargaining for teachers, and under ILO Convention 87 , following the banning of trade union membership at the Government Communication Headquarters (GCHQ)

As in the public sector so in the private. Legislation perceived (often in the face of research evidence to the contrary) as erecting barriers in the way of efficient management, or as hindering management's right to manage, has been amended. For the most part this has meant a weakening of the legal employment protections for workers enacted in the 1960s and 1970s (for example making it harder to pursue unfair dismissal claims), but it has also involved a reduction in the already limited wage protection which some workers in Britain have under the Wages Council system (with the denunciation of ILO Convention 26). Even so, the notoriously low rates set by the Councils in particular trades were seen as causing rigidities in the labour market and preventing the creation of jobs and so their scope has been narrowed and young workers removed from their protection. Downward pressure on wages has also been exerted through yout employment schemes where the government's assistance to employers has depended on the payment of low wages.

Although ILO Conventions are not seen as an impediment to government policy, the British government does not have an entirely free hand since Britain needs to be aware of 
its obligations as a member of the European Economic Community. Thus, rather against the general trend, we have seen increased protection for workers, and curbs on managerial prerogative, in the areas of health, safety and equal rights, with, for example, the introduction of the concept of equal pay for work of equal value. Where possible, however the British government seeks to minimise or block developments of this kind. It has mproving protections for part-time and tem other member states, and is actively opposing the 'social dimension' of the European Single Market in 1992.

In the rest of this paper I will consider the major elements of the legislative thrust since 1979 which directly affect trade unions and then to consider the impact and union response, returning at the end to the question of whether British unions are learning to live with the law. Three elements of the legislative thrust will be considered: the move away from collective industrial relations; the restricted terrain for lawful industrial action and legal intervention in internal union affairs.

\section{The legislative attack I: the move away from collective industrial relations}

In the 1960s the Donovan Report echoed what had been public policy since the last century, namely that collective bargaining was the best method of conducting industrial relations. This view had encouraged indirect support for collective bargaining as the mainstay of the vountary system (for example by generalising collectively agreed term through such devices as the Fair Watges Resolution and by providing state-funded volun 1970 s, more direct support through a statutory recognition procedure whereby unions 1970 s, more direct support through a statu
could seek bargaining rights from employers.

Since 1979 , in contrast, legislative supports to collective bargaining have been
seuld seek bargaining rights from employers. removed. Thus, for example, there is no longer any duty on employers to recognise a trade union for collective bargaining whatever its membership among employees. Trade unions have been thrown back on their own resources in attempting to persuade employers unich unions have traditionally used in organising have been made unlawful. The legal changes hinder the use of collective strength in one employment to put pressure on anothe employer to recognise the union. The inclusion of clauses in commercial contracts requiring work to be done only by union labour or by companies recognising trade union is outlawed and any industrial action seeking to achieve this will be unlawful (Lewis and Evans, 1982, p. 227-233).

At the same time the government has sought to promote non-unionism. Referring to the Employment Act 1982, Secretary for State Tebbit said;

we have enacted the most comprehensive and most effective statutory protection for non-union employees that we have ever had (quoted in Wedderburn, 1982 , p. 18)

It had been recognised previously in public policy in Britain that, whereas the right to belong to a trade union was both an individual freedom and a prerequisite for collective freedom, the right not to belong, although also a matter of individual freedom, could freedom, the right not to belong, although also a matter of individual freedom, could This "functional" (von Prondzynski, 1984, p. 10) approach to the freedom of association,

1 This article will not attempt to provide any detailed legal analysis of the legislation This may be obtained from, for example, Wedderburn (1980) and Lewis (1985). which is clearly related to support for collective organisation and collective bargaining, is rejected by the current legislation which adopts the individual approach. There is a statutory right not to belong to any trade union and enhanced monetary compensation (payable by the union) for those dismissed for refusing to join a union. ${ }^{2}$ Linked to this protection for the non-unionist has been the removal of legal support for compulsory union membership (the closed shop). ${ }^{3}$

The story of the legal undermining of the closed shop is a good example of the Thatcher administrations' legislative strategy which has been to adopt a 'step-by-step' approach, with each statute building on its predecessor and pushing restriction a little further. Rather than seek to outlaw the closed shop directly, the first major statute extended the statutory exemption which people could claim if they wished to remain nonmembers and keep their jobs. Previously those with religious objections were exempted from any requirement of compulsory membership. The list was extended considerably to cover, for example, those with personal convictions against union membership or membership of any particular union; those who hadn't been in the union when the closed shop agreement was made; and those who felt membership would conflict with a professional code of ethics. The next step in the strategy was to say that, even where the exemption did not apply, it would still not be permissible to dismiss a non-unionist in order to secure the closed shop unless a ballot of employees had been held in which 85 percent of those voting (or 80 percent of those eligible to vote) expressed their support of the closed shop. The final step was taken in the Employment Act 1988 when protection for the non-unionist was made absolute - whether or not a closed shop agreement was in existence, approved by the required majority of employees or not.

Recalling the earlier observation about the importance of the context within which legislation is enacted, it is important to sketch in the current climate within which trade unions are seeking to organise, to recruit and retain members, and to gain collective bargaining rights from employers, without any legal support and, to some extent, in the face of legal hostility. There are a number of long term shifts working themselves out in the labour market and structure of employment; shifts which adversely affect trade union membership. Briefly, these shifts are away from employment in areas where British trade unions have been well organised to areas of employment where membership densities have been lower and recruitment and retention problems particularly acute (data on employment trends and union membership from Dickens, 1988; and Bain, 1988).

The manufacturing industry (where union density averages around 70 percent), has declined to account for only about a fifth of total employment in 1987, while the service sector (where union density averages around 17 percent, with pockets as low as 5 percent) has grown to account for over two thirds of employment, a trend forecast to continue. This broad sectoral shift involves a move away from mass enterprise to more dispersed, smaller employment units. Within the remaining manufacturing sector plant size is also decreasing - and increasing plant size is positively correlated with union organisation. There has also been some relocation within the manufacturing sector, with new plants being established away from the traditional heartlands of industry and union organisation. New entrant employers often display an unwillingness to grant bargaining rights,

2 Someone sacked for refusing to join a union whom the employer refuses to reinstate may Whard is around $£ 12,000$. Where the union is found to have put pressure on the employer to dismiss non-unionists compensation is payable by the union. These levels of compensation are far higher than those awarded against employers for unjust discharge for reasons other than those connected with union membership. The median award in such cases is around $£ 18,000$.

3 The most common form of compulsory union membership in Britain arises from the postentry closed shop: where new employees are required to join the union within a postenty closed shop: where new enployees are required to join the union with a arrangements. 
particularly some foreign (especially American) multi-nationals, and the legal framework partictoral (a) shift is also associated with the growth of female part-time employment. Female participation in the workforce has been increasing and women now constitute over 45 percent of employees, almost half of them working part-time. Generally women are less likely to be in unions than men, with female/male union densities of 39 percent and 63 percent respectively, and part-time workers are less organised than full-time. The service percent is such as sector is also associated, who are not usually in unions.

Unemployment and sectoral shifts have negatively affected trade union membership. 1979 was the high point of union membership in Britain with 54 percent of the workforce organised - an increase of 10 percent compared to a decade earlier. But by 1986 three million members had been lost - 22 percent of the total - and density dropped to 42 million members had seem high by some international percent. Union membership in Britar - their own upward trend standards, but the unions' point of comparison is more par some unions in particular the in the 1970s and record membership levels in 1979. For some unions in particular the membership decline in the 1980s has been dramatic, although the are signs that the membership loss may now have halted. The three largest unions affiliated to the Trades Union Congress - the Transport and General Workers Union (TGWU), the Amalgamated Engineering Union (AEU) and the General Municipal Boilermakers and Allied Trades Engineering Union (AEU) and the Genera and 29 percent of their respective memberships Union (GMB) - lost 39

It is against such a background that the removal of legal supports for collective It is against such a background that the removal of legal supports for collective organisation and the legislative push to non-unionism is to be evaluated. At a time when sectoral and labour market change heightens the value of positive legal support to aid union organisation, such support is removed. In a context where some employers are questioning the appropriateness or functional value of collective bargaining, some of the questioning the appropriateness or function have been made unlawful.

\section{The legislative attack II: diminishing freedom to take industrial action}

Various developments have occured to increase the risk of taking industrial action for . The law now make it easier for employers to dismis workers and their unithe changes have placed a heavier workers on strike without penalty and social security chis the immunities, which define the freedom to take industral action. Protection from tort action is necessary for workers and unions to engage in industrial action at all and freedom to take industrial action in Britain is granted by statutory immunity from the common law the rope of the immunity in effect narrowed, making unlawful things which were previously lawful.

The legal effect of these changes is to confine lawful industrial action, and associated phenomena such as picketing, to a much narrower terrain than previously. Workers are able to take lawful industrial action only when the issue in dispute concerns their own terms and conditions and their own employer. No longer does protection extend to disputes between workers and workers (exposing demarcation and jurisdictional disputes) nor to disputes between workers and employers in general. This requirement that for in industral action to be lawful it must be selfat most sympathetic or solidarity actions, which now fall outside the protection of the immunity. But it also can cause problems for workers who think they are taking action against their own employer but find that corporate identity and legal reality do not always conform to worker perceptions. The National Union of Journalists, for example, fell foul of the law when it took industrial action against a Company B which, despite having the same shareholders as Company A, which employed the NUJ members, and despite being controlled by the same holding company, was in law a separate entity. ${ }^{4} \mathrm{~A}$ recent dispute involving the transfer of The Times and Sun newspapers to a new location with the dismissal of the 5,000 print workers and withdrawal of union recognition indicated how mate separate corporate entities (for example to handle printing, distribution, supplies and advertising) which effectively renders nearly all industrial action unlawful since the targets of such action are not in law the workers' own employer or those with whom the employer is in direct commercial dealing (Labour Research, 1986; and Wedderburn, 1986, pp. 604-5).

A further narrowing of the protection has been effected by requiring that disputes must be 'wholly or mainly related' to a list of subjects which can constitute a trade dispute. The trade dispute list is unchanged and would encompass most industrial relations disputes, but the previous definition required only that a dispute must be 'connected' with something on the list. The importance of the change was demonstrated soon after it was made by a case in which post office engineers refused to connect a private company into the British Telecom (BT) network. This was prior to the selling off of British Telecom at a time when the public sector monopoly was being removed by granting private companies a license to operate. To do so, however, the private company needed to be connected to the BT network. BT suspended the engineers who refused to make the connection and industrial action ensued. The question which arose was whether the engineers' action constituted a trade dispute and thus was protected by the immunity. The court held that, although the dispute was connected with fears about job loss which might arise through privatisation, it mainly arose out of a dislike of the government's privatisation policy. Previously the dispute would have been lawful since it was clearly connected to a permitted topic but the new definition pushed it outside the immunity - it became a 'political' strike. ${ }^{5}$ The problems for unions operating in the public sector where the line between industrial and political is blurred are obvious. The case also shows the important role for the courts in determining what industrial action is 'really' about and whether the immunity applies, and the uncertainty that will face unions until judicial determination is made.

The position described so far is what had been effected after the passage of the Employment Acts 1980 and 1982. In step-by-step fashion, the Trade Union Act 1984 went further - restricting the protection of the immunity to those cases where the taking of industrial action has been approved beforehand by a majority in a secret ballot of individual members. The statute specifies conditions with which the balloting has to comply, including the inclusion on the ballot paper of a statement that industrial action may involve workers in a breach of their contracts of employment, but provides no safeguards against interference in the ballot by employers or others. Although workers now have the right to express their views as to whether industrial action should take place, the law does not require them to be bound by the decision of the majority when the majority favours such action. The Employment Act 1988 provides that trade unions shall not discipline any member who disobeys an instruction to take lawful industrial action. Strikebreakers are protected.

The terrain for lawful industrial action, therefore, has been narrowed to the confines of own employer and own terms and conditions of employment, when approved by a majority of workers affected voting in a secret ballot and when not 'political'. The collective strength of workers in one area cannot be used to support workers in areas lacking it - solidarity is replaced by self-interest (Wedderburn, 1985).

To encourage unions to ensure that they and their members keep within this narrowed terrain the penalties for unlawful action have been changed. The blanket immunity 
previously enjoyed by British trade unions has gone. Removing union protection from liability means injunctions (court orders to cease some specific action) can now be sought against trade unions rather than individuals. This prevents substitution (for example, of new. pickets to replace those individuals served with an injunction) and avoids martyrs, instead exposing unions to contempt of court actions if the court injunctions are not obeyed. Such actions can result in unlimited fines which, as one judge put it in a recen case involving unlawful picketing by members of the National Union of Seafarers, could bleed a union to death. ${ }^{6}$ Further, it means that employers can seek damages (subject to maxima depending on union size) from union general funds for loss occasioned by unlawful action. The threat to union finances is designed to ensure union officials act cautiously when contemplating industrial action, and that if spontaneous or unofficial action occurs, leaders, mindful of their funds, either take control of it or actively repudiate it.

\section{The legislative attack III: intervention in union affairs}

As noted, the requirement for pre-industrial action ballots was introduced by the Trade Union Act of 1984. This statute was presented as enhancing union democracy by 'giving unions back to their members' and is all about ballots - ballots for industrial action ballots for union elections, and ballots to set up or continue funds to finance political activity. The theme indicated earlier of an attack on collectivist ideology and solidarity can be detected here too. The TUA 1984 can be seen in part as an attempt to give prominence to individualistic values within trade union decision making, seeing trade prominence to individualistic values within trade union decision making,
unions not as collective organisations but as mere aggregates of individuals.

The TUA 1984, as extended by the Employment Act 1988, requires all members of the leading bodies of trade unions (usually called the National Executive Committee (NEC)) and the senior official, to be elected at least every five years by secret postal ballot of the membership. A variety of methods used by British trade unions are no longer acceptable. These include appointment, election for life, indirect election via an electoral college system, and election by annual conference of the union. The significance of this legislation needs to be seen not only in terms of the impact which the changes may occasion within trade unions, but also in the fact of the interference itself. Exactly what was meant by voluntarism is open to some debate but it is clear, as Flanders noted, that for the unions a central tenet of the voluntary system was that they were free to regulate their own internal affairs (Flanders, 1974, p. 362). There has thus been union outrage at the fact of intervention as much as its nature, particularly, unions argue, in the absence of any real justification for it.

There may well be justification for the state seeking to regulate internal union affairs. As Martin suggests, these may include corruption, protection of individual rights in situation where union membership is compulsory and as a quid pro quo for state support (Martin, 1985, pp. 78-9). These rationales do not appear to be applicable in this case however. Corruption is not a problem within British trade unions and the Government did not seek to provide evidence to the contrary in support of its intervention. As noted, the compulsory membership aspect is being tackled by removing the legal supports for the

The NUS dispute which started in the Spring of 1988 involved $\mathrm{P} \& \mathrm{O}$ as the primary employer but members took action in various ports around the country and othe companies were affected by what was deemed to be secondary action. Picketing a Dover, the main port in the dispute, was also held to be unlawful. In the first five months of this protracted dispute the union faced eight legal actions. By the end of July 1988 the union had already been fined a total of $£ 350,000$ and had its $£ 2.8$ million assets sequestrated by the courts. closed shop and the state is not seeking to provide positive assistance for unions as a quid
pro quo, rather the opposite.

Unions also argue they are being subjected to increasing regulation at a time when decreasing regulation, or 'deregulation', is the approach towards employers. Employers are being freed from legal 'burdens' (for example by the weakening of workers' legal protections and removal of regulations governing such matters as hours of work) and yet increasing duties are being imposed upon the unions. The Employment Act 1988 , for example, increases the range of rights which individual members can exercise against their trade unions, including a right to inspect the union's accounting records, accompanied by an accountant if the member so wishes. That Act also creates a new government official the Commissioner for the Rights of Trade Union Members - who will provide assistance, including legal and financial assistance to individuals wishing to exercise their rights against their trade union. against their trade union. No equivalent assistance is provided for individuals wishing to exercise their legal rights against employers although the lack of help of this kind has been highlighted by research to be an important factor which limits the effectiveness of statutory employment protection provisions (Dickens et al., 1985, pp. 85-96; Justice Department, 1987, pp. 13-5; and Leonard, 1987, pp. 124-30).

These then are the main elements in the legislative attack on trade unions: an attempt to restrict collective organisation and demote collective bargaining, to restrict industria action and curb union power, and to alter the nature of trade unions.

\section{Impact and response}

Much of the legislation is quite recent - the Employment Act 1988 is only jus coming into effect at the time of writing - and we need a longer term in which to asses the impact of the total legislative package (if, indeed, this is the total package - a new Employment Bill has been announced and the step-by-step approach does not preclude even further steps being taken if the government there are some signs that this may be the case). ${ }^{7}$ There is also the ever present problem of isolating any impact of legislation from other factors. However it is possible to say something about the immediate impacts, including the nature of the response to the legislation

We should note first of all that the law is of two different kinds: some aspects of the legislation require unions to take specific action in order to be in compliance, for example to change union rules where necessary to comply with the new ballot requirements for union elections; whereas the impact of other provisions largely rests on employers or other injured parties invoking legal remedies against unions. We should also note that although we are talking about the impact on unions in general terms, within the union movement different unions are in different circumstances and will experience the legislation, or elements of it, differently. This is perhaps most obvious in terms of the ballot requirements; for example, some unions (albeit a minority) already elected their general secretaries in the way now required by statute, whereas others appointed them or

In November 1988 the Department of Employment issued a Draft Code of Practice on Trade Union Industrial Action Balloting which goes considerably beyond the existing statute law. For example, it suggests that unions might look to achieving at least 70 percent support in a ballot for industrial action before endorsing it; that they should attempt to 'pre-poll' to see if members actually want a ballot before calling one; and that unions should allow the employers an opportunity to supply their description of the reason for the ballot being held. A Code issued by the government is not legally enforceable as such but its provisions are admissible as evidence in any court proceedings. Some observers see this as 'legislating by the back door' or as a precurser to more restrictive legislation (Financial Times, 1988). 
elected by some indirect method, neither approach being now legally acceptable. ${ }^{8}$ But the impact also applies more generally. Thus, for example, unions who made particular use of the now outlawed organising strategies (using established strength to block the goods of a non-union employer for example, or insisting that sub-contract work had to be done by union labour), or those whose membership or bargaining strength was underpinned by the closed shop, will feel the potential impact of the law more intensely than those for whom these were not important features, and we have already highlighted the particular problems which the narrowing of the immunity raises for public sector unions.

If we consider those areas of the legislation which require unions to take action to come into compliance, we find that they have generally done so. The TUA 1984 requirement that a union with a political fund (without which political activity, including support for parliamentary candidates or the mounting of campaigns around 'political' issues, cannot be financed) has to gain membership support for such a fund in a secret ballot every ten years sent a shiver through the Labour Movement. The British Labour Party gets 80 percent of its finance from the union movement via the political funds yet it was known that in the 1983 General Election the majority of trade unionists had not voted for the Labour Party. Individual members have the right to opt out of payment to the political fund and in some 15 unions the majority of the membership in fact opted out. Would members support the continuation of the fund?

Many of the unions with funds set them up in the years after 1913, when the framework for the legal regulation of expenditure by trade unions on political objectives was first laid down, so they were subject to immediate ballot. The unions mounted very active a mail inerwhelming 'yes' votes to continue their funds. The turnout was generally very high in these ballots and among the 37 TUC unions balloting to retain their funds an average level of support of 83 percent was obtained, ranging from 59 percent to 93 percent (Steele et al., 1986). Furthermore, some unions previously without political funds decided to set them up and secured membership support. These new funds may be seen in large part as a consequence of changes to the definition of political activity made by the Act which created uncertainty about the legality of union expenditure on campaigns about aspects of government policy (for example expenditure cuts absence of such a fund. The unexpected success of the 'political voice' campaigns heartened the unions. It showed what could be achieved through direct communication with the members and by actively seeking membership support, and removed one of the fears which the new emphasis on ballots had occasioned.

Changing union rules to provide for election of NEC members and general secretaries by individual membership secret ballot had proceeded more slowly - and with one or two legal prods initiated by disgruntled members following elections carried out under unreformed rules. However, rule changes are being made in unions including some of the largest such as the TGWU and the GMB. In the former the executive was elected by regional or group committees rather than the whole membership directly; while in the latter the General Secretary was elected by branch block voting, with the whole vote of the branch being given to the successful candidate. It is difficult to know what impact the was argued to be to make unions 'become and be seen to become more democratic and more truly representative of their members' interests' (Democracy in Trade Unions 1983) and reflected a government view that individual memberhip postal ballots would increase the influence of moderation and lead to the election of more 'responsible' union leaders. The equation of individual membership ballot with democracy displays little sensitivity to the existence of subtle, competing and equally valid concepts of democracy (different unions can appear more or less democratic depending on the concept adopted) which has engaged academic discussion (for an overview see Undy and Martin 1984, ch.5), nor to the particular historical and organisational considerations which gave rise to the variety of different practices within British trade unions. Nonetheless, rule changes do have the potential to affect the balance of power within trade unions, to affect the development and effectiveness of factions and to influence the degree of participation and the role of opinion formers. The exact nature and out omes of participation however, are far less easy to predict and there is no anarantee that the government achieve the kind of union leaders it appear same type as before, but with increased autority - resting on the same type as before, but with increased authority - resting on the mass 'democratic' support of all the membership (Edmonds, 1986).

The third ballot area covered by the TUA 1984 concerns the necessity for majority support to have been obtained in a secret ballot before any industrial action in order to claim protection of the legal immunities, narrowed by Employment Acts 1980 and 1982. (It should be recalled that in the British system industrial action is not confined to the end of the contract but may occur at any time, over both 'rights' and 'interest' issues). Here we move to an area where much depends on the willingness of employers to seek legal remedies. A union which does not comply with the balloting requirement is acting unlawfully but faces no sanction if those affected by the action opt not to seek the legal redress available to them. There is still strike action occuring in Britain without ballot approval and without any legal challenge being mounted. In 1985/6 there were 1030 officially recorded stoppages, and only some 246 pre-strike ballots, but, as we see below, in only a tiny proportion of cases was there any recourse to the co

Nonetheless lack of a prop employers faced with industrial action issue is clear issue is clear cut and employers can present their action as upholding workers' rights rather than attacking the union. It buys time for the employer if the union is instructed it must hold a ballot, forces the union to show its hand in terms of its industrial action tactics, since all those likely to be called to take part have to be balloted, and, of course, the membership may vote 'no'. The fact that the lack of a ballot is left unchallenged in a the of industrial action, however, indicates that employers see that ballots can be doubedged. The membership may vote' 'yes', har their authority making it their authority, making it harder to negotiate a compromise and resulting in employer concessions having to be made. In three quarters of the 246 ballots mentioned above majority membership support was obtained but in only 20 cases (11 percent) did industrial action then occur (Dickens, 1987). The inference here must be that the ballot result fed back into negotiation and led to a shift in the employer's position leading to a settlement. Certainly it appears that the calling of a ballot is feeding into negotiation tactics - whether and when one might be called and the guess as to the outcome becoming part of the bargaining arsenal.

Reasons other than those indicated above may be suggested as to why employers might not use the law to insist on a ballot: recourse to the courts may help the union mobilise support and escalate the action or may adversely affect the longer term bargaining relationship, making the underlying dispute harder to resolve. It was this kind of anis. which underpinned a widespread assessment made by unions and academics alike thas British employers would be reluctant to seck legat and their trade unions. and their trade unions. Experience under the Industrial Relations Act 1971, when legal remedies were also available to employers faced with industrial action but were little used, reinforced such analysis (Weekes et al., 1975, pp. 201-213). But experience under the new legislation has emphasised that such reluctance is contingent and in the changed circumstances of the 1980s recourse to legal remedies has a employers that it apparently had in the 1970s. There has certainly been greater for some new provisions then of tho 1984 there 1984 there were 34 injunctions sought and from 1984 to 1987 (after the industrial action ballot requirement was added to the narrowed immunities) there were 80 (Evans, 1987; and 
Labour research, 1988). Furthermore, recourse to the courts has been successful for those employers concerned - injunctions are almost always granted and where industrial action had been underway it has ceased or collapsed.

However, these hundred or so cases hardly constitute a stampede to the courts by employers and closer examination, such as that undertaken by Evans, reveals a sectoral clustering of employers (printing, shipping and public services taking most of the cases) and suggests that the law provides a useful tool for employers who are pushing through radical change in busines strategies in the face of union opposition, in a position where such change is perceived as necessary for their survival, and, in particular, in circumstances where the management is not committed to a continuing relationship with the union (the newspaper relocation dispute mentioned earlier is a good case in point) the union (the newspaper relocation dispute mentioned earlier is a good case in point)
(Evans, 1987). Not all employers are in this position and the disadvantages of seeking legal remedies weigh more heavily with them. ${ }^{9}$ Not all employers are mounting offensives and much change is being achieved through negotiation and union acquiescence. Evans' work also suggests that the use of the law is in fact most effective when used to expose already weak support for industrial action rather than in an attempt to weaken support already committed. Thus we can identify factors which make the employers using the law 'special'. Nonetheless, the membership of this special club does seem to be the law 'special'. Nonetheless, the membership of this special club does seem to be
growing and an increasing number of union general secretaries have enjoyed the experience of being served with court writ. Since 1979 some 29 different unions have faced the courts, covering around 80 percent of TUC membership, and all are having to be attentive to the possibility.

The consequences of union defiance of law or lack of union control over unlawful industrial action have been made very clear by the courts who have not hesitated to impose fines for contempt of court and to sequestrate union assets if fines remain unpaid, charging the union the cost of sequestration. This, rather than employer action for damages, has been the main depleter of union funds. The possibility now open to employers of pursuing damages claims, however, has been used tactically. For example, British Rail, who successfully obtained an injunction against the rail union for unlawful action, kept alive the threat of a damages action to recover losses occasioned by the action during the subsequent negotiations until it had achieved the results it sought. And it was only in February 1988 that the car producer Austin Rover finally announced it would not pursue an action for damages against seven unions who had taken unlawful action in 1984 (the first case to come before the courts of no ballot, no immunity).

\section{Learning to live with the law?}

Because employers are displaying a willingness to seek legal remedies, if only in certain circumstances, and the courts are backing up their orders with heavy financial sanctions, unions are in one sense having to learn to live with the law. We have also noted that unions have discovered that they may in fact be able to use the legal provisions to aid their own position (for example the role of ballots in bargaining) and ballots appear to be liked by many union members. It is also significant that the unions, in contrast again to the Industrial Relations Act 1971, have failed to mount any effective campaign against the legislation. An eight point plan drawn up at a special meeting of the TUC unions in 1983 included the refusal of state money to finance ballots (at that time voluntary), refusa to seek approval for closed shops through ballots as required, and the promise of support for any union falling foul of the new provisions. The plan crumbled quickly. Unions, like the AEU and EEPTU, which already carried out ballots under their own rules, saw no

9 But it should be noted that the Employment Act 1988 reduces employer control over whether legal action will be taken to insist on a ballot by giving individual members the right to seek an injunction against the union where a ballot is not held. reason why they should not get reimbursed by the state. After an acrimonious period TUC policy was modified and other unions have now joined them in obtaining reimbursement of ballot expenses. Unions at local level began to hold closed shop ballots where they thought they would win them, despite national policy, and when it came to the where they thought they would win them, despite national policy, and when it came to the
crunch did, as print unions faced injunctions under the new legislation - the TUC failed to deliver the support asked for, fearing that by so doing it would itself be acting unlawfully.

In part, British unions' and employers' attitudes towards compliance with, and the use of, labour law depends on its perceived permanency and, particularly after the return of Mrs Thatcher's Government in 1983, it became clear that there was no immediate prospect of a quick repeal or legislative change, as there was during the short lifetime of the Industrial Relations Act. What is more, it is now the case that short lifetime of the Industrial Relations Act. What is more, it is now the case that even if a sympathetic Labour Government were to be returned there is no longer a commitment on the part of Labour Party leadership to repealing all the Thatcher legislation, although changes are likely to again adjust the balance between employers and unions. A future Labour Government would also be likely to remove those provisions (such as the right of an individual to strike break without fear of union discipline) against which employers as well as unions have argued. ${ }^{10}$ Further, as time goes on, union leaders are being elected under new rules within trade unions and they, like all leaders, will no doubt consider the system by which they were elected as a fair and just one.

But the question of whether the unions are learning to live with the law raises a more fundamental issue than their adjustment to the present legal framework, namely the attitude of the trade unions to the role of law in industrial relations more generally.

The fragility of the voluntarist system has been rudely exposed by the ease with which measures supportive of collective bargaining were removed and the immunity narrowed with the 'right' to strike in Britain being shown to rest on rather shaky foundations. Economic conditions of the 1980s have helped expose the fragility of collective bargaining when unions are weakened and no legal underpinnings exist to stop collective breaking agreements (collective agreements remain back' facilities for workplace tra unionism, such), 'rollin bargaining, or even, in a few bargaining, or even, in a few cases, withdrawing recognition from trade unions altogether. The features of the changing labour market and employment structure indicated earlier have also brought home to some unions the problems of organising and servicing members by relying solely upon their own efforts in the face of employer hostility. In some there has been an acknowledgement too that, even in the voluntarist. In some quarters of collective bargaining were never universal - collective bargaining was always limited in scope and coverage and has offered little to some of the 'mar. are now appor are now apparently growing in importance (Dickens, 1988, pp. 143-4, 148-51). Also, in a time of reduced bargaining power some unions have found that the existence of statutory protections for workers (often there because of European requirements) have provided with much needed levers in bargaining, as for instance in the case of hrovided them 1986).

Considerations such as these have altered the character of the debate in the union movement and among sympathetic academic commentators concerning the role of law. The view expressed to the Donovan Commission that the unions wanted no more from

As this indicates, employers have not been wholly supportive of the legislative attack. Certainly important employer organisations such as the Confederation of British Industry - the peak employer organisation - and the Engineering Employers Federation who perhaps are more collective bargaining minded than those employers represented in small firm lobbying groups or the Institute of Directors, have argued against certain elements of the legislative package including those which they perceive as going too far in undermining union discipline which can, after all, be deployed in ways which management. 
the law than that it should be kept away has given way to some rather detailed discussion as to the kind of legal framework which unions should be seeking. The TUC is of the view that 'law is in industrial relations and cannot now be excluded' (Trade Union Congress, 1986) and the 1986 Congress pledged the unions to maintain strike ballots, introduce a National Minimum Wage and to extend employment protection rights. At its 1988 Congress the TUC welcomed the European 'social dimension', anticipating an extension of legal rights. Debate goes on over issues such as whether a positive right to strike would fare better than an immunity; what an effective statutory procedure for obtaining bargaining rights might look like; how the enactment of individual legal rights might be used to aid trade unions, as well as improve employment protection; what new legal duties should be imposed on employers regarding worker participation in the enterprise and whether there should be a system of labour courts to handle industrial relations legislation (McCarthy, 1985; Fabian Society, 1988; TUC-Labour Party, 1986; and Wedderburn, 1987).

To some extent one might argue this is no Pauline conversion but a reemergence of the pragmatic approach to law which characterised the voluntary system. But although the voluntary system, as we saw, allowed scope for a secondary role for law, the current debate, unlike earlier discussions, has lost its 'return to voluntarism' thrust. In addressing its two pragmatic concerns of recruitment/organisation in a changed employment context and of declining bargaining power in the context of de-regulatory/restrictionist labour law there does appear to be a growing feeling in the union movement that there is a need for law to do more than just provide procedural safeguards for a voluntary system and plug a few gaps (von Prondzynski, 1985). Inasmuch as the unions' earlier hesitation to call in aid from legal regulation was based on the view, expressed by the TUC in its evidence to the Donovan Commission (Royal Commission on Trade Unions and Employers' Associations, 1968, p. 142), that 'what the law gives, the law can take away' (with references often made to the experience of United States unions), it has been seen that even if the law doesn't give, it can still help to take away, and the voluntary system has shown itself unable to withstand the actions of a hostile government. Consequently, many important unions are talking about legal regulation in a way almost unthinkable twenty years ago. There always have been differences in the attitude towards legal regulation between unions, and of course there still are, but the dominant tenor of the debate has shifted. There may be severe difficulties in attempting to translate the current debate about positive, pro-worker, pro-union legal provisions into legislative action when (if) the time comes, and a changed context may well make the task appear less pressing. But it is perhaps learning to live with the law in the sense of union and academic reassessment of labour law traditions which will be the longer term legacy of the post 1979 labour legislation.

\section{References}

Bain, G S (1988) The changing context of industrial relations in Britain University of Warwick mimeo.

Beaumont, P (1987) The Government as a model employer: a change of direction in Britain? Journal of collective negotiations 16(3).

Democracy in trade unions (1983) Cmnd. 8778, London, HMSO.

Dept. of Justice (1987) Industrial Tribunals pp. 13-5.

Dickens, L et al. (1985) Dismissed, a study of unfair dismissal and the industrial tribunal system Oxford, Blackwell.
Dickens, L (1987) A positive vote for ballots? Industrial law journal 16(3):204-5.

Dickens, L (1988) Falling through the net: employment change and worker protection Industrial relations journal 19(2):140-4.

Edmonds, J (1986) Trade union democracy Warwick papers in industrial relations.

Ferner, A (1985) Political constraints and management strategies: the case of working practices in British Rail British journal of industrial relations XXII(1).

Evans, S (1987) The use of injunctions in industrial disputes May 1984 - April 1987 British journal of industrial relations XXV(3):419-429.

Ferner, A and Terry, M (1985) The crunch had come: a case study of changing industrial relations in the Post Office Warwick papers in industrial relations.

Financial Times (1988) 4th November, p. 13.

Flanders, A (1974) The tradition of voluntarism British journal of industrial relations XII (3):352.

Hayek, F A (1980) Unemployment and the unions, 1980s: the distortion of relative wages by monopoly in the labour market London, Institute of Economic Affairs.

Kahn-Freund, O (1954) Legal framework. In Flanders, A and Clegg, H A (eds) The system of industrial relations in Great Britain Oxford, Blackwell, p. 44.

Kahn-Freund, O (1977) Labour and the law 2nd ed., London, Stevens.

Labour research (1986) Courts aid Murdoch in print dispute March:3.

Labour research (1988) Tightening the legal grip around union necks September:7.

Leonard, A (1987) Judging inequality London, Cobden Trust.

Lewis, R and Evans, A (1982) Disorganising industrial relations Industrial law journal 11(4):227-233.

Lewis, R (ed) (1985) Labour law in Britain Oxford, Blackwell.

McCarthy, W (1985) Freedom at work: towards the reform of Tory employment laws Fabian Society.

McCarthy, W (1988) The future of industrial democracy Fabian Society.

MacInnes, J (1987) Thatcherism at work Milton Keynes.

Martin, R (1985) Ballots and trade union democracy: the role of government. In Fosh, P and Littler, C Industrial relations and the law in the 1980s Gower, pp.78-9.

Royal Commission on Trade Unions and Employers' Associations (1968) Selected written evidence HMSO. 
Steele, M et al. (1986) The Trade Union Act 1984: political fund ballots British journal of industrial relations XXIV(3):456-60.

TUC - Labour Party (1986) People at work: new rights, new responsibilities.

TUC - Labour Party (1986) Low pay: policies and priorities.

Trade Union Congress (1986) Industrial relations legislation.

Turner, D (1986) Equal pay as a bargaining lever Personnel management June:38-41.

Undy, R and Martin, R (1984) Ballots and trade union democracy Oxford, Blackwell.

von Prondzynski, F (1984) Freedom of association in modern industrial relations Industrial relations journal 15(1):10.

von Prondzynski, F (1985) The changing functions of labour law. In Fosh, P and Littler, C Industrial relations and the law in the 1980s Gower, p. 189.

Wedderburn, K W (Lord) (1982) Tory boot goes in New Socialist May/June:18.

Wedderburn, K W (Lord) (1985) The new policies in industrial relations law. In Fosh, $\mathrm{P}$ and Littler, C Industrial relations and the law in the 1980s Gower, p. 43.

Wedderburn, K W (Lord) (1986) The worker and the law 3rd ed. Penguin.

Wedderburn, K W (Lord) (1987) Labour law: from here to autonomy? Industrial law journal 16(1):1-29.

Weekes, B et al. (1975) Industrial relations and the limits of law Oxford, Blackwell.

Younson, F (1984) Who's been using the law in industrial disputes? Personnel management June:33-5. 